\title{
Stakeholders Perspective of an Ideal Board of Director in Pakistan: A Survey from Pakistan
}

\section{Habib $M^{*}$}

Muhammad Ali Jinnah University, Islamabad, Pakistan

*Corresponding author: Habib M, Muhammad Ali Jinnah University, Islamabad, Pakistan, Tel: 922134311325; E-mail: maryam.habib2011@yahoo.com

Received date: October 31, 2015; Accepted date: December 01, 2015; Published date: December 04, 2015

Copyright: (c) 2015 Habib M. This is an open-access article distributed under the terms of the Creative Commons Attribution License, which permits unrestricted use, distribution and reproduction in any medium, provided the original author and source are credited.

\begin{abstract}
The main purpose of this study was to formulate a perceived model from stakeholder's perspective of an ideal board of director in Pakistan. For this study we have reviewed critically the developed and developing nation's family controlled companies. A perceived model for Pakistani companies was proposed after studying the pros and cons of the existing model. A suggestion has been made for SECP that a good quality of board, a good quality of individual director and a good board performance can be achieved according to this perceived model of stakeholders. Nonexecutive directors (NEDs) and independent executive directors (INEDs) will be encompassing in entire perceived board. The aim of this perceived model would be overcome the main source of poor board in Pakistan i.e., to fill the board in the sense of ensuring the balance of representation, talent, size, power and social responsibility.

This survey is about stakeholder's perspective an ideal board of directors in Pakistan. This survey underlines the stakeholder's perspectives; respondents were provided a list of 37 indicators of board of directors and asked to rank the indicators according to their order of preference. No.1 meant to be the most preferred indicator that was talent on the board, No.2 representation of all stakeholders, No.3 NED/INEDs structure on board, No.4 balance size of the board, No.5 power on the board and No.6 CSR meant to be the least preferred indicator. The researcher identify knowledge gap when it comes to examine in Pakistan.
\end{abstract}

Keywords: Stakeholder; Governing activities; Local community; Security exchange commission

\section{Introduction}

Corporate governance is a way of governing activities of a corporation for the well-being of all stakeholders (not only for shareholders) that ultimately leads to better financial performance. It is the set of process, customs, policies, laws, and institutions affecting the way a corporation (or company) is directed, administered or controlled. "Corporate governance refers to the manner in which the affairs of a corporate body are or should be conducted in order to serve and protect the individual and collective interests of all stakeholders". It has been commonly observed that corporate governance is not implemented in any of the firm/organization of Pakistan in true sense. After the financial crisis of world in the last two decades, the focus of the researchers has been changed from shareholder approach to stakeholders. SECP has issued and finalized the first Code of Corporate Governance for Pakistan in March 2002. All public listed companies of the three stock exchanges were subsequently incorporated in the listing regulations and are now applicable. In Pakistan the first institutional effort of its kind is the code. To safeguard the interests of diversified stakeholders and to establish a system the primary aim of the code whereby with the best practices a company is directed and controlled by its directors in compliance. The representation by minority shareholders and by executive and non-executive directors and to introduce and proposes the restructuring of the board of directors. For the stakeholders larger interest of all in a transparent, informed, diligent and timely manner and directors to discharge their fiduciary responsibilities. The code emphasizes openness and transparency in corporate affairs and the decision-making process.
Author has been motivated to conduct the research and defines stakeholders and shareholders. Stakeholder is anyone that has an interest or is affected by a corporation. In other words, the shareholder isn't the only party having a stake in the corporation. Other stakeholders in a corporation include the employees, the employees' families, suppliers, customers, community, and others. Some organizations do not have shareholders, but have stakeholders. For example, the state university doesn't have shareholders but it has many stakeholders: students, the students' families, professors, administrators, employees, state taxpayers, the local community, the state community, society in general, custodians, suppliers, etc. according to author comparison between the stakeholders and shareholders. The shareholders are stakeholders in a corporation but stakeholders are not always shareholders. A shareholder owns part of a company through stock ownership while a stakeholder is interested in the performance of a company for reasons other than just stock appreciation.

Stakeholders are any individuals or group who can effect by achievement of organizational objective i.e., Stakeholders are government, customer, shareholder, employees and suppliers. After the understanding of stakeholder's interest the next question arises whether all or any one of them should be a member of board or not because the business affairs shall be managed under the direction of board. Unfortunately the current managerial model focus only on companies' shareholders interest and earnings are measure of all the success [1]. By using the agency theory author is motivated to explain where principle is the (shareholder) director is the (watch dog) and manager is the (agent). The interest of large companies shareholders are attached to the company only a few have chance to protect their 
interest. A group of people run the companies that have no concerned in others interest.

\section{Statement of the Problem}

It has been observed according to corporate governance perspective in Pakistan most of the companies are owned by families or some groups. Board is badly affected by the dominate shareholders that owns more than $50 \%$ of shares. The directors are elected by these majority, these elected directors may be a part of controlling family or employee of the family controlling. Only these shareholders make decisions and put influenced on the companies only for their own interest. Mostly large companies remained in the hands of a single shareholder or a small pool of shareholders. The board is ineffective here and played in the hands of executive directors, that are taking injustice decisions and underhand dealing about the companies and approving the wrong financial statements. Many researchers have investigated various feature / facts of corporate boards. What is the ideal board structure from stakeholder's perspective? Very less theories is provided for effectiveness of board structure of the company. It is shown that only board monitoring and improving governance are the features of effective board. "The intention of the current research is to explore the stakeholder preferences for board structure, size, and board composition" $[2,3]$.

\section{Research objective}

The main objective of this study is to highlights the loop holes in structuring a board that was followed / practicing by all board directors. It is a survey from Pakistan; author will attempt to suggest the board structure, size, composition and individual qualities from stakeholder's perspective for board of directors in Pakistan. Effectiveness of board depends on board of directors and its features.

This is a survey of board of directors of good companies held to explore these questions well as examine the effect of directors on board structure. This study also highlights and focuses on either the survey data support or contradicts the corporate governance literature. Perspective of companies objective is to balance the conflicting interest and managing all stakeholders and through performance of board of directors who are elected by different groups. Criticism of corporate board structure have increased. They investigates the board functions and independence of board [4].

The goal for the current research is to focus on the ideal stakeholder perspective board structure working in Pakistan and to pay attention to the interest of minority shareholder and all stakeholders.

\section{Significance of the study}

In Pakistan, Security Exchange Commission of Pakistan (SECP) issued a Code of Corporate Governance in 2002 which was revised in 2012. In this paper author will put emphasis on stakeholders to suggest the ideal structure of board from their perspectives and to suggest regarding global developments in corporate governance and upgrading the objectives of corporate governance in Pakistan.

The aim of this current study is to fill this gap from stakeholder's perspective of ideal board structure, size, composition, responsibilities and individual qualities. The current study will also highlight which kind of board structure is required from stakeholder's perspective? And the mode of making decision in the company's board.
The current study will also pay attention to minority shareholders and beneficial be to all stakeholders interest.

The current paper would also recommend SECP to dove tail these new standards for practical implementation for the help of all stakeholders.

\section{Conclusion}

Corporate governance practices are considered to be supportive of capital markets. There are a large number of researches reflecting that companies having better governance mechanism attract capital and are considered credible both by shareholders and lenders. The companies that comply with the principles of good governance benefit national economies as a whole they not only lead to better financial performance but also fuel growth generate opportunities for employment improve the quality and variety of their product and contribute manifolds in improving the quality of life for the public at large.

In the context of Pakistan, there is a difference in corporate governance run-throughs when compared with companies of developed economies.

Big families and closed groups are mostly controlling the companies in Pakistan wherein the individual directors or the Board of Directors have minimal control over business decisions thus compromising the effectiveness of company operations/business.

Big families and closed groups are mostly controlling the companies in Pakistan wherein the individual directors or the Board of Directors have minimal control over business decisions thus compromising the effectiveness of company operations/business.

The present study deliberated on the stakeholder's perspective of an Ideal Board of Director. The dissection of Quality of Board of Directors reveals that there is high percentage of directors with little or no knowledge of their company's business in the Pakistani corporate environment. A large number of companies are owned by small group of individuals or families, which constitute certain amount of subjectivity and thus comprise the quality of crafting any effective strategy or sound mission with any long term vision by the corporate bodies. The BODS in Pakistan are generally believed to be not well informed with regards to varying business trends in the competitive market environment and are often struggling to devise effective measures in the face of market hicks and hitches. Another important fact is that the Company matters are not adequately discussed in the Company meetings or are dominated by big shareholders or other influential stakeholders, thus limiting the space of communicative rationality and chances of efficiently resolving issues.

\section{Recommendations}

The rule of law on disclosure especially transactions of related parties and ownership should be focus and enforced by SECP. With this regards three areas seems to be very important. First, the control and beneficial ownership disclosure; Second, related parties transactions way of reporting; third, with respect to the AGM the compliance of company.

- The enforcement capability of SECP should continue to enhance. The technical size and level of staff in critical areas like accounting etc. steps should be taken by SECP to increase the strength for this purpose. 
Citation: Habib M (2015) Stakeholders Perspective of an Ideal Board of Director in Pakistan: A Survey from Pakistan. Arts Social Sci J 6: 149.

- Issues particular related to all accounting, legal and technical in code of corporate governance procedures should refine enforcement by SECP.

- The independent non-executive director (INED) must be a chairman board of directors.

- The expertise and experience related to the area of financial reporting the audit committee must have a member with all the knowledge.

- Some ADHOC committees are recommended in order to handle the burning issues faced by the company.

- On quarterly basis the stakeholders should be disclosed with the statements regarding financial performance of the business.

- In the article of association/charter of the company the independent non-executive director (INED) qualification should be clearly define.

- The periodical trainings are strongly recommended for the directors under the supervision of Pakistan Institute of Corporate Governance (PICG) in order to keep abreast with latest development in the area of corporation.

- The other functional restriction requirements, including director tenure, retirement, succession and policies limiting the number of boards on which a director may sit, must also be taken into consideration by SECP.

- What is expected from a director, including advance review of meeting materials and basic duties and responsibilities with respect to attendance at board meetings these responsibilities should clearly articulate.

- To determine whether it and its committees are functioning effectively a self-evaluation at least annually should be conducted by the board.

- For identifying, screening and recommending candidates for the Board membership the responsibility is on Corporate Governance Committee.
- The optimum number of directors is between 7 and 9 as currently believes by the Board.

- No immediate family members (i.e., spouse, parents, children, siblings, mothers and fathers-in-law, sons and daughters-in-law, brothers and sisters-in-law and anyone (other than domestic employees) who shares the Director's home) who did not satisfy an independent director.

- Directors should carefully consider the number of other boards on which they can serve consistent with the time and energy necessary to satisfy the requirements of Board and Committee memberships.

- More research is needed in this area. The researcher can also use to study this issue more with large sample size and by including other characteristics i.e., attitude of board, gender representation, compensation, functions of board etc.

\section{References}

1. Gilbert DT, Krull DS, Pelham BW (1988) Of Thoughts Unspoken Social Inference and the Self-regulation of Behavior. Journal of Personality and Social Psychology 55: 685-694.

2. John K, Senbet LW (1998) Corporate governance and board effectiveness. Journal of Banking and Finance 22: 371-403.

3. Hermalin BE, Weisbach MS (2003) Boards of Directors as an Endogenously Determined Institution: A Survey of the Economic Literature. Economic Policy Review 9: 7-26.

4. Jensen MC, Meckling WH (1976) Theory of the Firm: Managerial Behavior, Agency Cost and Ownership Structure. Journal of Financial Economics 3: 305-360. 